\title{
2 波長マッハツェンダー干渉法を用いたレーザー支持爆轟波構造の解明*1 Structure Analysis of Laser Supported Detonation Waves by Two-Wavelength Mach-Zehnder Interferometer
}

\author{
嶋 村 耕 平*2. 畑 井啓 吾*3 . 河 村 好 一*2. 福 井章 泰*3.福 田 章 雄*2 \\ Kohei Shimamura, Keigo Hatai, Koichi Kawamura, Akihiro Fukui, Akio Fukuda, \\ 王涁*2 · 山口 敏 和*2 · 紫 公 也*2 ·荒 川 義 博*3
}

Bin Wang, Toshikazu Yamaguchi, Kimiya Komurasaki and Yoshihiro Arakawa

Key Words : Space Propulsion, Laser Detonation, Laser Propulsion, Plasma Diagnosis

\begin{abstract}
To investigate the internal structure of LSD waves, electron density distribution $n_{\mathrm{e}}$ was measured by two-wavelength Mach-Zehnder interferometer and electron temperature $T_{\mathrm{e}}$ was by emission spectroscopy. As a result, peak values of $n_{\mathrm{e}}$ and $T_{\mathrm{e}}$ were about $2 \times 10^{24} \mathrm{~m}^{-3}$ and $30,000 \mathrm{~K}$, respectively. Based on the measured properties, laser absorption coefficient was calculated. It showed that incident laser energy was perfectly absorbed in a layer much thinner than a plasma layer, situation of which was not predicted by the conventional LSD model. Measured $n_{\mathrm{e}}$ at the shock front was not zero while LSD was supported. This suggested that the precursor electrons exist ahead of the shock wave.
\end{abstract}

\section{記号の説明}

$$
\begin{aligned}
A_{\mathrm{ij}} & : \text { アインシュタイン倸数 } \\
a & : \text { 音速 } \\
c & : \text { 光速 } \\
D & : \text { 衝撃波の伝播速度 } \\
d & : \text { ガラス板間の距離 } \\
e & : \text { 素電荷 } \\
G & : \text { Gaunt 因子 } \\
g_{\mathrm{j}} & : \text { 縮退度 } \\
h & : \text { プランク定数 }
\end{aligned}
$$

$h_{1}, h_{2}:$ 干渉縞の移動本数

$K:$ 比屈折率の数密度係数

$k:$ 逆制動放射吸収係数

$k_{\mathrm{B}}:$ ボルツマン定数

$l:$ レーザー吸収層の厚み

$m$ : 質量

$n:$ 数密度

$n_{0}:$ 参照光路の気体数密度

$r: \mathrm{LSD}$ 波面に打けるレーザービームの半径

$S: \mathrm{LSD}$ 波面に扔けるレーザー強度

$T:$ 温度

$T_{\mathrm{ex}}:$ 電子励起温度

$t:$ ブレークダウンからの経過時間

\footnotetext{
*1 (C) 2010 日本航空宇宙学会

平成 22 年 6 月 24 日原稿受付

*2 東京大学大学院新領域創成科学研究科先端エネルギー工学専攻

*3 東京大学大学院工学系研究科航空宇宙工学専攻
}

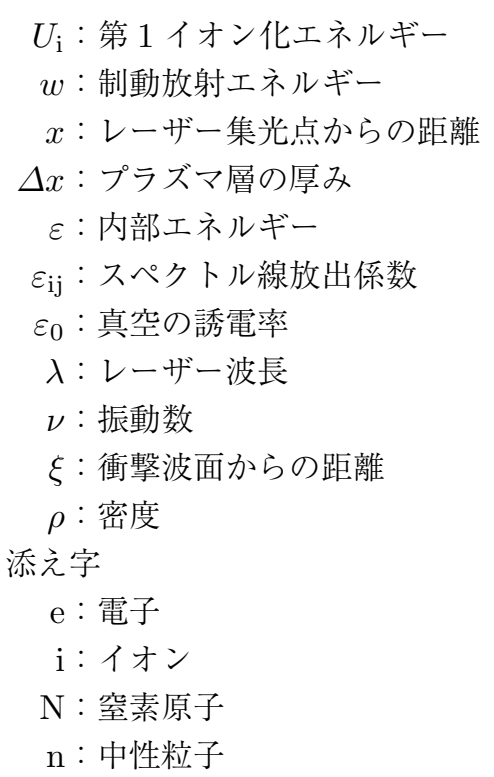

1. は じめに

大気吸い込み式 RP (Repetitively Pulsed) レーザー推 進1〜5) は, 地上から繰り返しパルスレーザーにより供給さ れたエネルギーを推進に用いる推進機関である。機体下部 の放物面鏡でビームを集光して焦点付近にプラズマを誘起 させると, 気体の急激な膨張により爆風波が生じる。 その際 にレーザー支持爆轟 (Laser Supported Detonation; LSD) 波が生じ，衝撃波は強められ，ビームエネルギーを吸収し 衝撃波のエンタルピに変換される。 それを機体後部のノズ ルで受けとめ推力を得る.

燃焼反応に伴うデトネーションでは衝撃波と燃焼領域が 
隣接して伝播するが，LSDの場合は燃焼領域の代わりにプ ラズマによるレーザー吸収領域が存在する，LSD 領域では 気体はほぼ定積的に加熱されて衝撃波へとエネルギーが変 換されるが，レーザー強度がある程度小さくなると LSD は 終了する。衝撃波とレーザー吸収領域は離れ，衝撃波後方 の気体が定圧的に加熱されるのみで, 衝撃波はほぼ断熱的 に伝播する。このため LSD 終了後に投入されたレーザー エネルギーは推力に寄与しない. LSD の構造や維持するた めの条件を明らかにすることが推進機の最適設計にとって 重要な課題である.

Raizer ${ }^{6)}$ は, LSD の終了条件として，レーザー加熱によ るエネルギー入力と爆風波波面を伝って流れ出るエネルギー 損失のバランスに注目し,$r$ と $l$ の比がある值よりも小さ くなると LSD が終了するというモデルを提案している．ま た，LSD は衝撃波誘起の反応ではなく，衝撃波よりも先行 する種電子がレーザーを吸収することによってその背後に 衝撃波を誘起している可能性を指摘している.

森ら7 9) は, シャドウグラフ法により, TEA $\mathrm{CO}_{2}$ レー ザーで点集光されたレーザー誘起プラズマを観察し，LSD が維持されるレーザー強度值を様々な集光 $F$ 值やレーザー エネルギー, 雲囲気圧力について調べている。またシュリー レン法を用い, 衝撃波面の伝播履歴から爆風波エネルギー を求め, 高速気流中での実験や, 圧力への依存性も調べて いる. 牛尾ら ${ }^{10)}$ はレーザーを線状集光し， LSD の伝播を 2 次元, 準 1 次元空間に限定することでエンタルピの LSD 領 域からの流失を制限し, その維持条件と爆風波エネルギー 変換効率を求めている.

これら一連の研究では，波面伝播速度に現れる LSD 特性 を計測しているものの, レーザー吸収層の厚みなどの LSD 波内部構造を実測した例はこれまでになく，また，先行す る種電子に関しても定量的な測定は行われておらず，検証 が必要である。

本研究では過去の研究と同様に, TEA $\mathrm{CO}_{2}$ レーザーの ビームを線状集光することに誘起される爆風波 ${ }^{10)} に$ 関して, 2 波長マッハツェンダー干渉法と発光分光法を用いて $l$ や $\Delta x$ の評価を行い，それらの時間変化と LSD 終了の因果関 係を調べて Raizer モデルを検証するとともに，衝撃波に先 行する種電子について考察を行った。

\section{2. 電子密度分布の測定}

実験に用いた TEA $\mathrm{CO}_{2}$ レーザー $(\lambda=10.6 \mu \mathrm{m}$, $10 \mathrm{~J} / \mathrm{pulse}$ ) のレーザーパルスの波形を第 1 図に示す。鋭 いピークに続いて指数関数的に減衰するテール波形が見 られ，ピークの半值全幅及びテールの減衰時定数は各々， $0.12 \pm 0.02 \mu \mathrm{s}$ 及び $1.15 \pm 0.05 \mu \mathrm{s}$ であり, エネルギーのパ ルスごとのばらつきは $\pm 5 \%$ 以下であった.

このレーザーより射出された半径 $15 \mathrm{~mm}$ のビームを焦 点距離 $48 \mathrm{~mm}$ の 2 次元非軸放物面鏡によって線状に集光 し，アルミ板上に照射した。レーザーは着火直後からすべ て周辺気体に吸収されるため, アルミ板にアブレーション 痕は認められなかった ${ }^{10)}$ 。幅 $30 \mathrm{~mm}$ のプラズマは光学的

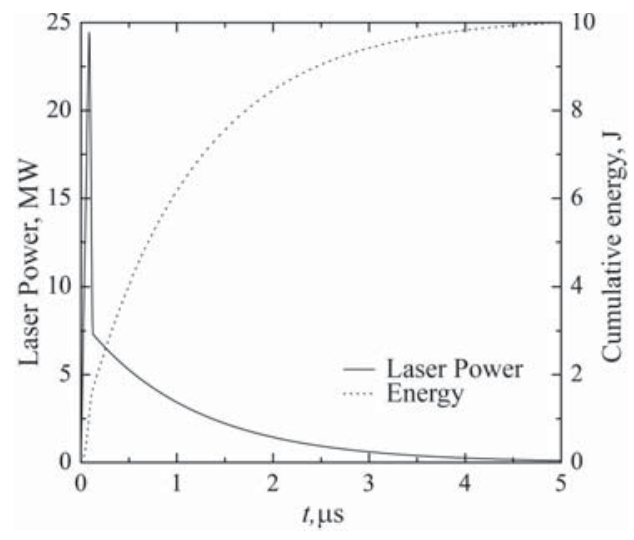

第 1 図 レーザーパルス波形

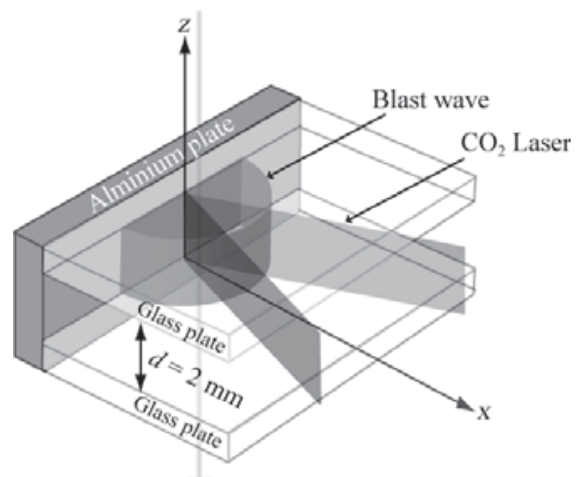

Probe Laser

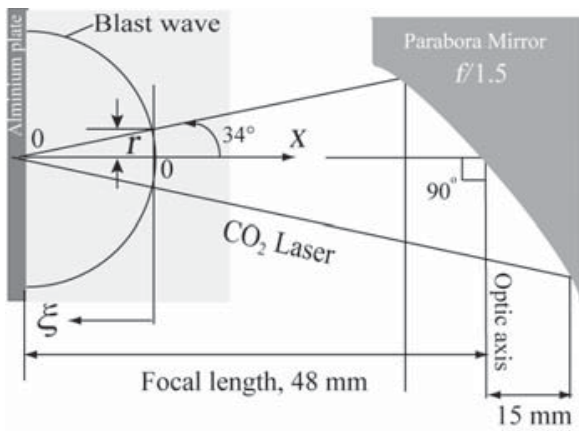

第 2 図 レーザー集光系

に厚すぎるため, 一対のガラス板を用いて第 2 図のように $d=2 \mathrm{~mm}$ だけ離した 2 枚のガラス板の間に LSD 波を生 成した。 $d=30 \mathrm{~mm}$ と $2 \mathrm{~mm}$ の場合で衝撃波の伝播に違い は見られず， $t=1.2 \mu \mathrm{s}$ から $1.3 \mu \mathrm{s}$ で LSD は終了した，本 実験では $t=1.3 \mu \mathrm{s}$ 前後の時間帯で計測を行った.

マッハッェンダー干渉法は空気力学における可視化の 1 つの手段であり，流れの密度分布を求められる. 非接触で流 れを乱さず，応答が速い非定常の現象に適している ${ }^{111}$.今 回の実験は移動干渉縞法を用い，電子の密度分布を測定し た．移動干渉縞法は 2 つのレーザー光路をわずかにずらし， 観測前に干渉縞を作る方法で, 測定対象の密度の変化量に 応じて干渉縞が移動する。

2 波長マッハツェンダー干渉計を第 3 図に示す。プラズ マの干渉縞は電子と重粒子の影響を受けるため, 単色光の 


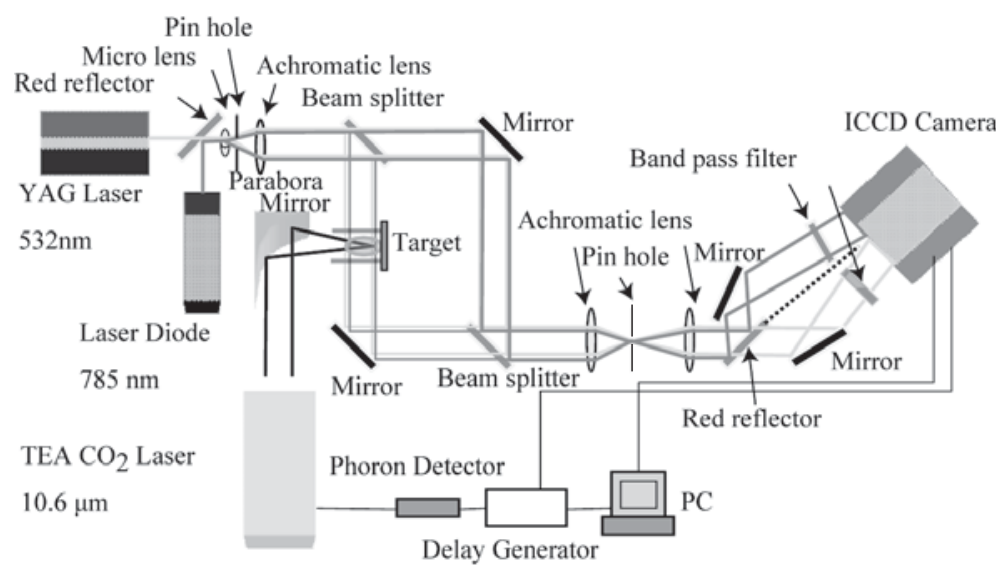

第3 図 2 波長マッハッェンダー干渉計

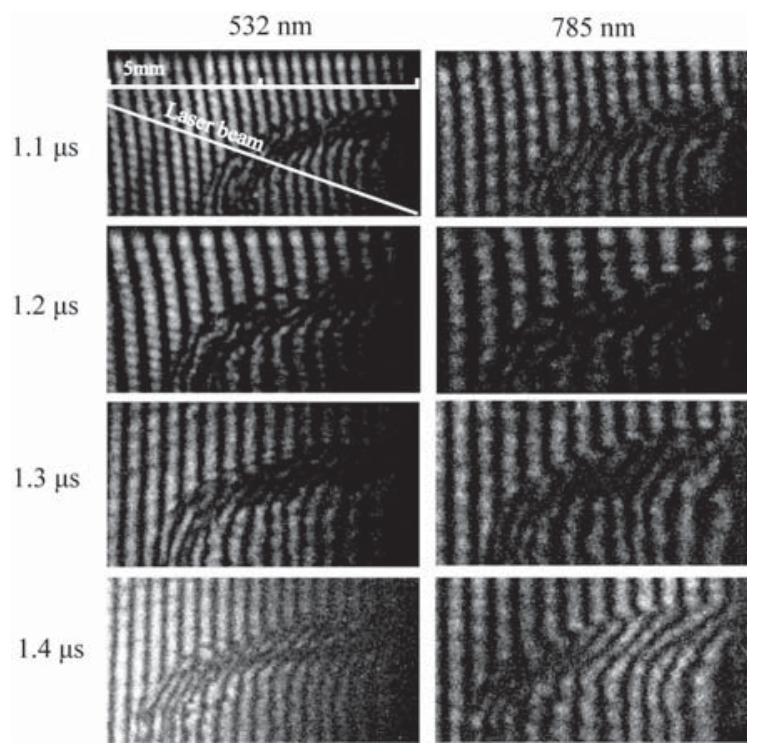

第 4 図 生成されたレーザー爆風波周囲の干渉縞 レーザーは左側から照射されている. $t=1.3 \mu \mathrm{s}$ 付近で LSD が終了する。

干涉計では $n_{\mathrm{e}}$ を独立して求めることができない.

そこで電子の屈折率のみがプローブ光の波長に依存する 性質を利用し， 2 波長のプローブ光で $n_{\mathrm{e}}$ を測定した。プ ローブ光には Nd:YAG レーザー 2 次高調波 $(\lambda=532 \mathrm{~nm}$, 出力 $8 \mathrm{~mW})$ 及び赤外半導体レーザー $(\lambda=785 \mathrm{~nm}$, 出 力 $50 \mathrm{~mW}$ を用いた. $\mathrm{CO}_{2}$ レーザーのギャップスイッチ 放電光をトリガー信号とし, 遅延回路 (Stanford Research Systems, Inc.) を介して ICCD カメラ $(1,024 \times 1,024$ 素 子, Andor Technology 社製）に任意のタイミングで撮影 用トリガー信号を送り撮影した. 2 つのプローブ光は Red reflector を介して同一の光軸に合流し, 干渉計を通過し た後, Red reflector によって分けられ各波長のバンドパ スフィルター（785 $\pm 1 \mathrm{~nm}$ および $532 \pm 1 \mathrm{~nm})$ を通過後, ICCD カメラにて同時に撮影される。レンズはすべて波長 収差のないアクロマチックレンズを使用した。

撮影された干渉縞画像を第 4 図に示す. LSD 波はレー ザーの光軸面に対して対称であるため上半分の写真を撮影
した。レーザー軸と垂直な方向への衝撃波伝播マッハ数か ら，衝撃波面での不連続な縞の飛びの本数を理論的に計算 し, 爆風波内部の密度を見積もった。 2 次元の FFT フィル 夕を用いて高次のノイズを除去している。 $n_{\mathrm{e}}$ 及び $n_{\mathrm{n}}$ と干 渉縞の移動本数の関係は式 (1), (2) で表される.

$$
\begin{aligned}
n_{\mathrm{e}} & =\left(\frac{8 \pi^{2} c^{2} m_{\mathrm{e}} \varepsilon_{0}}{e^{2}}\right) \frac{h_{1} \lambda_{1}-h_{2} \lambda_{2}}{d\left(\lambda_{1}^{2}-\lambda_{2}^{2}\right)} \\
n_{\mathrm{n}} & =n_{0}+\frac{1}{K_{\mathrm{n}}}\left(\frac{h_{1} \lambda_{1}}{d}-K_{\mathrm{e}} n_{\mathrm{e}}-K_{\mathrm{i}} n_{\mathrm{i}}\right) \\
& =n_{0}+\frac{1}{K_{\mathrm{n}}} \frac{h_{1} \lambda_{1}}{d}-\frac{K_{\mathrm{e}}+K_{\mathrm{i}}}{K_{\mathrm{n}}} n_{\mathrm{e}}
\end{aligned}
$$

ここで添え字の 1,2 はそれぞれプローブ光の波長 $\lambda=532 \mathrm{~nm}$ 及び $\lambda=785 \mathrm{~nm}$ を表しており， $K_{\mathrm{n}}$ 及び $K_{\mathrm{i}}$ は数密度に依存せず, それぞれ $1.1 \times 10^{-29} \mathrm{~m}^{3}$ 及び $7.4 \times 10^{-30} \mathrm{~m}^{3}$ とした. 求めた中心軸上の $n_{\mathrm{e}}$ と $n_{\mathrm{n}}$ 分 布を第 5 図に示す。縞の間隔は最大で約 $1 \mathrm{~mm}$ であり，軸 方向の空間分解能はおよそ $0.1 \mathrm{~mm}$ である。 また, 照射レー ザー出力のばらつき等による誤差を 5 回の測定の標準偏差 (エラーバー) で示している。衝撃波背後に $n_{\mathrm{e}}$ のピークが 存在し，その最大值はおよそ $2 \times 10^{24} \mathrm{~m}^{-3}$ であり，時間 とともに減少した。 また $n_{\mathrm{e}}$ を補間した曲線を衝撃波面ま で延長すると， $t=1.2 \mu \mathrm{s}$ 以前に衝撃波面で $10^{23} \mathrm{~m}^{-3}$ の オーダーの密度の電子の存在を認めることができる， $n_{\mathrm{n}}$ に 関しては，LSD 波の伝播マッハ数と衝撃波関係式より求ま る $n_{\mathrm{n}}$ を実線で示している。爆風波内部のほぼ平らな数密 度分布が計測されている。

\section{3. 電子温度分布の測定}

3.1 電子温度の測定 発光分光の測定系を第 6 図に示 す. TEA $\mathrm{CO}_{2}$ レーザー及び集光光学系は上記の実験と同 様である. 生成したプラズマの発光をレンズ, 光ファイバー を経由して分光器に導く、レーザーとの同期方法は, 炭酸 ガスレーザー内のギャップスイッチの発光を光ファイバー で取り出し，フォトディテクタで電圧信号に変換する。こ れを分光器のシャッターコントローラーに導く.

一度の測定で広い波長領域の計測が可能なエッシェル型 

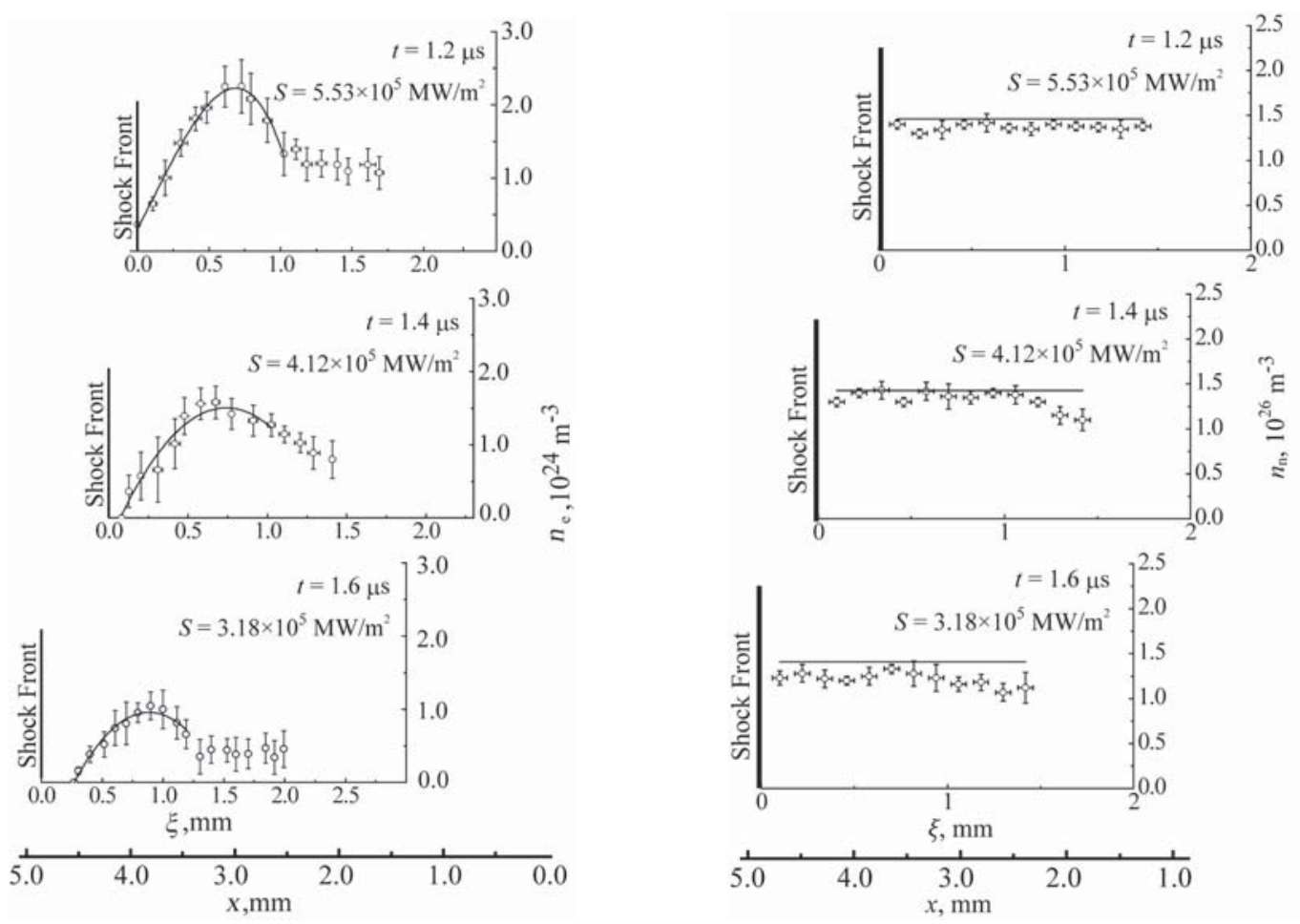

第 5 図 レーザー軸上の電子数密度分布（左）と中性粒子数密度分布（右） 左端は衝撃波面 (Shock Front) を示し, 全体の横軸が衝撃波面の移動距離を示す.

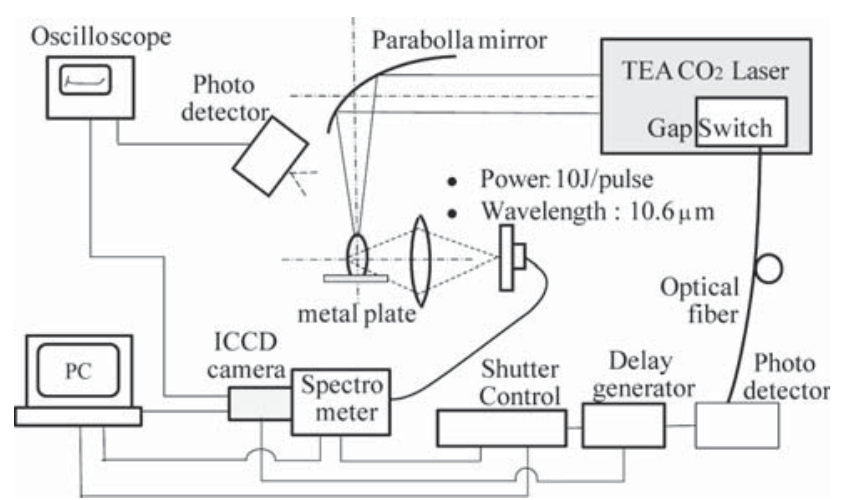

第 6 図 発光分光撮影系

分光器 (LTB 社製, ARYELLE200) を使用した。分解能 は $\lambda / \Delta \lambda=$ 約 8,000, 口径比は $f / 10$, 焦点距離は $200 \mathrm{~mm}$, 測定可能な波長領域は約 250 900 nm である。波長校正 は分光器付属の水銀灯を用い, 感度校正はハロゲンランプ を標準光源として利用した，プラズマ撮影部の光学系は立 体角が比較的大きい非球面コンデンサーレンズ（集光距離 $37 \mathrm{~mm}$, 直径 $50 \mathrm{~mm}$ ）を使用し, 発光領域のほぼ全域の光 を集めている。露光時間は $100 \mathrm{~ns}$ である.

スペクトル分布の一例を第 7 図に示す。主として, 原子 からの線スペクトル, 分子からのバンドスペクトル, 制動 輻射による連続スペクトルより成っている，NII のスペク トル線 7 本 $(399.500,444.703,463.054,500.515,504.510$, $567.602,594.165 \mathrm{~nm})$ についてボルッマンプロットを描い て $T_{\mathrm{ex}}$ を求め, 連続スペクトル成分に関しては Planck 関

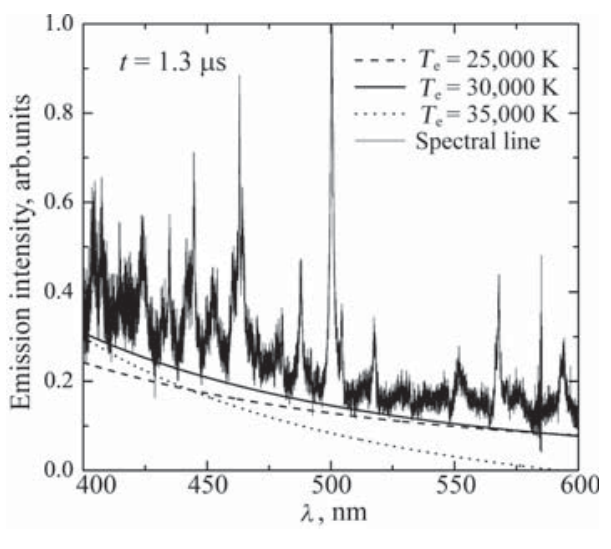

第 7 図 スペクトル分布

数でフィッティングし $T_{\mathrm{e}}$ を推定した. スペクトルのデータ はNIST のデータベースを利用した。 ボルッマンプロット を第 8 図に示す。また，窒素原子に対するボルッマンプロッ トより求めた $T_{\mathrm{e}}$ の時間履歴を第 9 図に示す。 $32,000 \mathrm{~K}$ 程 度から時間の経過とともに低下した。また第 7 図に示す連 続スペクトルから求めた $T_{\mathrm{e}}$ は $(3.0 \pm 0.2) \times 10^{4} \mathrm{~K}$ であっ た. $t=1.3 \mu \mathrm{s}$ 以降は原子の $T_{\mathrm{ex}}$ が $T_{\mathrm{e}}$ を下回り, 熱的非 平衡が生じている可能性があるが, この時間带では同一と みなして，ボルツマンプロットから求めた $T_{\mathrm{ex}}$ を $T_{\mathrm{e}}$ とし て以降の考察を行った。

3.2 電子温度分布の推定 3.1 節の電子温度計測は空間 分解能がなく, 計測された温度は発光の最も強い領域の情 報であると考えられる。熱化学平衡が成り立っているとす 


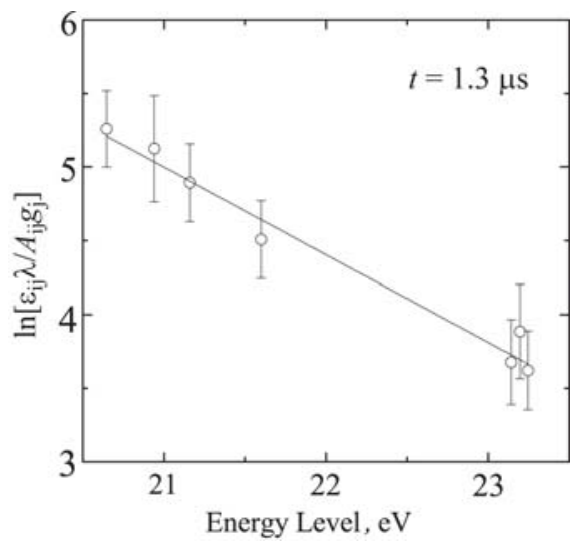

第 8 図 ボルツマンプロット

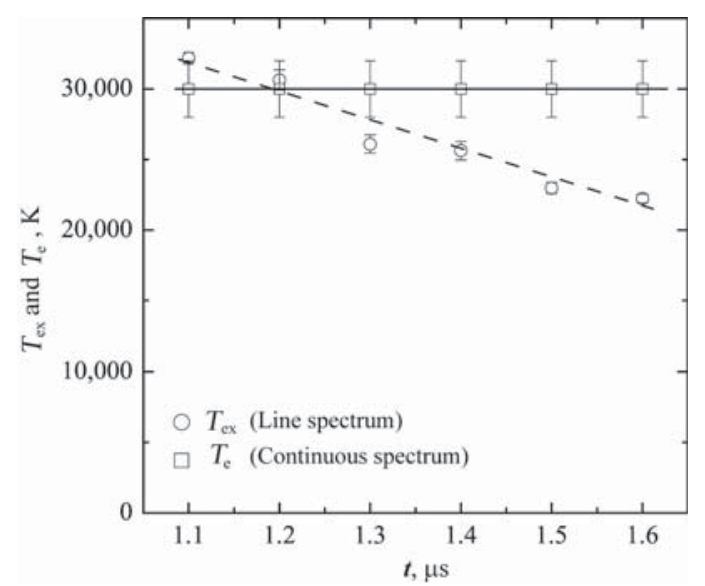

第 9 図＼cjkstart連続スペクトルによって測定された電子温度と線スペクトル によって測定された電子励起温度の時間履歴

ると, 発光が最も強い場所は $n_{\mathrm{e}}$ の最大点であり, $T_{\mathrm{e}}$ の最 高点でもあると考えられる, 窒素の解離度が不明なため, 主 たる電離反応 $\mathrm{N} \Leftrightarrow \mathrm{N}^{+}+\mathrm{e}^{-}$に関する Saha の電離平衡式

$$
\frac{n_{\mathrm{i}} n_{\mathrm{e}}}{n_{\mathrm{N}}+n_{\mathrm{e}}}=2 \frac{g_{\mathrm{i}}}{g_{\mathrm{n}}}\left(\frac{2 \pi m_{\mathrm{e}} k_{\mathrm{B}} T_{\mathrm{e}}}{h^{2}}\right)^{\frac{3}{2}} \exp \left(\frac{-U_{\mathrm{i}}}{k_{\mathrm{B}} T_{\mathrm{e}}}\right)
$$

から $n_{\mathrm{e}}$ の最大点で解離度を計算し, 解離度が衝撃波背後 で一様と仮定して, 計測した $n_{\mathrm{e}}$ 分布と Saha の平衡式を 再度用いて $T_{\mathrm{e}}$ 分布を求めた。結果を第 10 図に示す。

\section{4. レーザー吸収帯の構造}

4.1 レーザー吸収帯構造 第 5, 10 図に示した結果を 用いて, 衝撃波背後の $l$ の評価を行った. $\mathrm{CO}_{2}$ は比較的 長波長であるため, レーザー光の吸収はプラズマの逆制動 放射が支配的であるとされている，逆制動放射によるエネ ルギーの吸収係数は, 電子とイオン間 $k_{\mathrm{e}-\mathrm{i}}$ と電子と中性粒 子間 $k_{\mathrm{e}-\mathrm{n}}$ の吸収倸数の和として得られ， $T_{\mathrm{e}}$ の関数となる. 両者はそれぞれ，

$$
k_{\mathrm{e}-\mathrm{i}}=\frac{4}{3}\left(\frac{2 \pi}{3 m_{\mathrm{e}} k_{\mathrm{B}} T_{\mathrm{e}}}\right)^{\frac{1}{2}} \frac{e^{6} \lambda^{3}}{h c^{4} m_{\mathrm{e}}} G n_{\mathrm{e}} n_{\mathrm{i}}\left(e^{h c / \lambda k_{\mathrm{B}} T_{\mathrm{e}}}-1\right)
$$

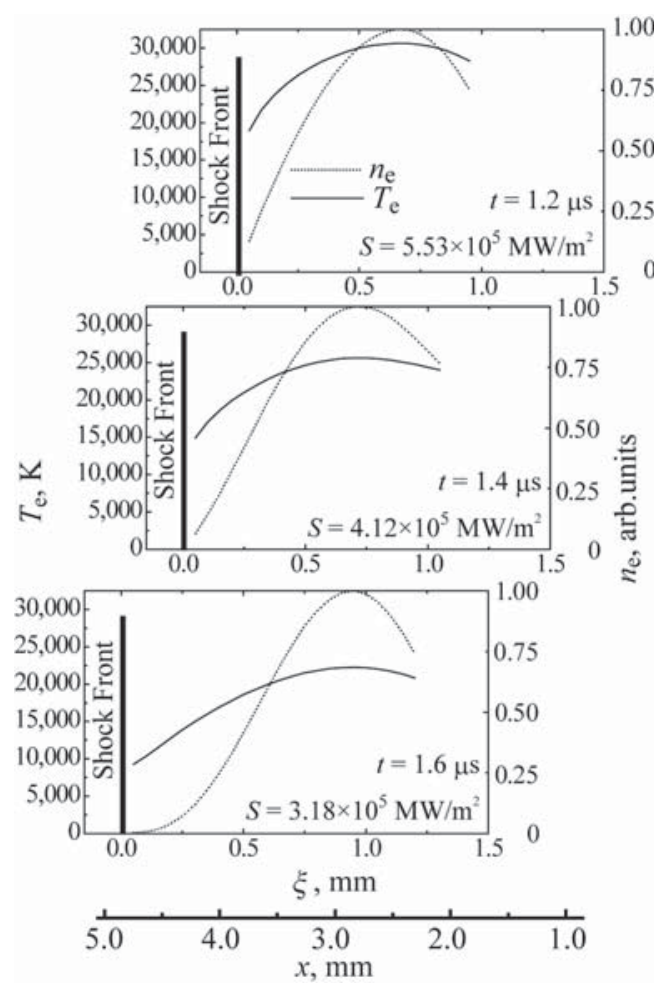

第 10 図 電子温度と電子密度の空間分布

$$
k_{\mathrm{e}-\mathrm{n}}=\frac{k_{\mathrm{B}} T_{\mathrm{e}}^{2} A\left(T_{\mathrm{e}}\right) \lambda^{3}}{h c} n_{\mathrm{e}} n_{\mathrm{n}}\left(1-e^{-h c / \lambda k_{\mathrm{B}} T_{\mathrm{e}}}\right)
$$

と表せる. $A\left(T_{\mathrm{e}}\right)$ は文献值である ${ }^{12)}$. 吸収係数の分布から, 以下の式を用いて局所レーザー強度を求め, 局所レーザー 加熱率を計算した，結果を第 11 図に示す。

$$
\frac{\mathrm{d}(2 r d S)}{\mathrm{d} x}=\left(k_{\mathrm{e}-\mathrm{i}}+k_{\mathrm{e}-\mathrm{n}}\right) 2 r d S
$$

局所レーザー強度は衝撃波前方の值で， $n_{\mathrm{e}}$ はピーク值 でそれぞれ規格化してある，どの時間带でもプラズマ層で レーザーが完全に吸収されることがわかる，実験でもこの 時間帯のレーザー透過は 0 であったことと良く符合する。 これは，予混合気体中を伝播するデトネーション反応層に おける完全燃焼と類似しており, $t=1.4 \mu \mathrm{s}$ より早い時刻 に执いては衝撃波近傍の薄い領域で高い加熱が起きている ことがわかる.

$l$ を透過レーザー強度が $1 / e$ に低下する距離と定義し, $\Delta x$ を衝撃波から $n_{\mathrm{e}}$ のピークまでの距離と定義して，そ れぞれの時間履歴を第 12 図に示す. $l$ は $S$ の低下に伴い 広がるが, $\Delta x$ はほとんど変化していない

4.2 Raizer モデルの検証 レーザー吸収帯で得られる エネルギーが衝撃波の伝播に寄与するエネルギーと横方向 への膨張で失われるエネルギーに分配されるとすると，こ の実験条件を用いてエネルギー流束の保存式は以下で表さ れる6).

$$
\rho D \varepsilon(2 r d)+\rho a \varepsilon(2 d \Delta x)=S(2 r d)
$$

とは電子のエネルギーが主であるとすると, 


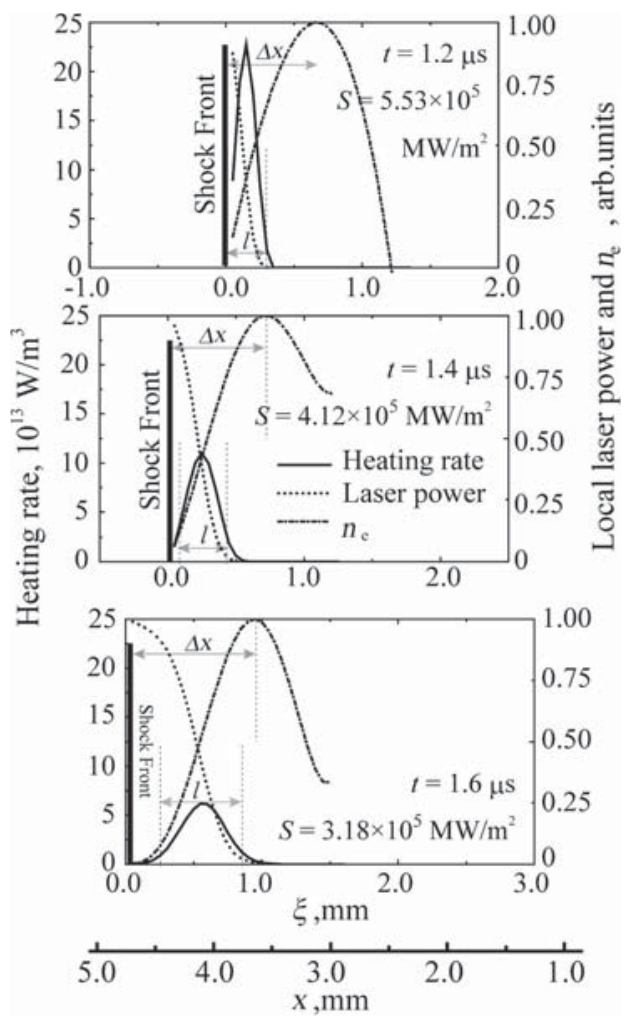

第 11 図 衝撃波背後のレーザー吸収帯構造

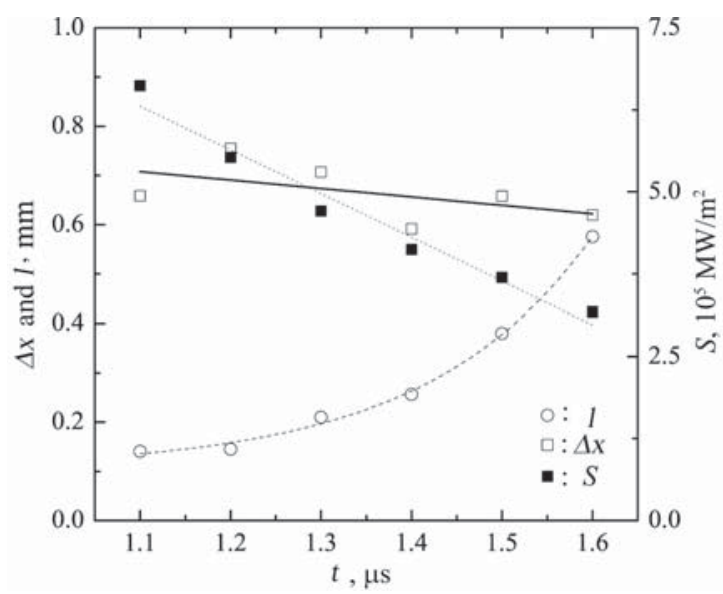

第 12 図 レーザー吸収帯の厚みとプラズマ領域長, レーザー強度の 時間変化

$$
\varepsilon\left(T_{\mathrm{e}}\right)=\frac{3}{2} n_{\mathrm{e}} k_{\mathrm{B}} T_{\mathrm{e}}
$$

と表される. Raizer モデルではレーザー強度 $S$ の減少に 伴って $\Delta x$ が拡大し, 式 (7) 左辺第 2 項が大きくなり $T_{\mathrm{e}}$ が 低下することが LSD 終了の原因であるとされている，しか し, 測定された $\Delta x$ はこの時間帯にほとんど変化しておら ず，レーザーに支持されていないプラズマがレーザー吸収 層背後に広く残存していることを示している。もちろん横 方向へのエネルギー流出は $T_{\mathrm{e}}$ の低下に大きな影響を及ぼ すが, LSD 終了条件をスケール比 $l / r$ あるいは $\Delta x / r$ の みで議論することは難しいことがわかった。

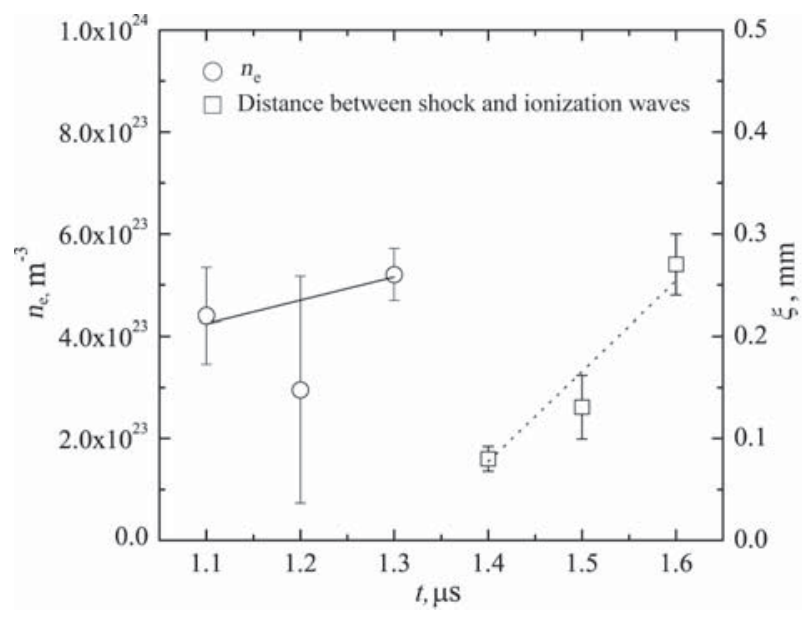

第 13 図 衝撃波面での $n_{\mathrm{e}}$ と電離波面と衝撃波面の距離の時間履歴

4.3 紫外域輻射光電離による種電子生成の可能性 プ ラズマ層から紫外域輻射による光電離が衝撃波面前方で種 電子を生成し，この電子がレーザーエネルギーを逆制動放 射で吸収することで指数関数的に密度が増大し, 衝撃波を 誘起している可能性がある。空気中の主たる成分の中では 酸素分子のイオン化エネルギーが最も低く $12.07 \mathrm{eV}$ であ り, 約 $100 \mathrm{~nm}$ 以下の波長の輻射が酸素分子の光電離に寄 与できる13). 単位時間に単位体積から $\nu \sim \nu+\mathrm{d} \nu$ の幅に放 射される制動放射のエネルギーは以下の式で表される。

$$
w(\nu) \mathrm{d} \nu=6.3 \times 10^{-53} \sqrt{\frac{e}{T_{\mathrm{e}}}} n_{\mathrm{e}} n_{\mathrm{i}} \exp \left(-\frac{h \nu}{T_{\mathrm{e}}}\right) \mathrm{d} \nu
$$

実験から得られた值を用いて推算すると， $T_{\mathrm{e}}$ を $30,000 \mathrm{~K}$, $n_{\mathrm{e}}, n_{\mathrm{i}}$ をともに $10^{24} \mathrm{~m}^{-3}$, 放射体積を $10^{-12} \mathrm{~m}^{-3}$ とすれ

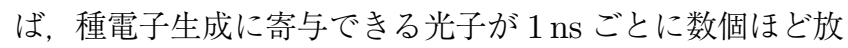
出されることになり，その可能性がある，第 13 図に衝撃波 面での $n_{\mathrm{e}}$ と電離波面と衝撃波面の距離の時間履歴を示す. $t=1.3 \mu \mathrm{s}$ までは衝撃波面にすでにプラズマが存在し, 衝 撃波より前方にもプラズマが存在することが示唆されてい る.このプラズマが消失すると同時にプラズマ層の最前面 （電離波面）が後退を始めている．また過去の研究における LSD 終了時間と今回の実験は一致した.

化学デトネーションでは衝撃波圧縮により燃焼反応が誘 起され，ZND 構造（あるいは衝撃波と反応層の距離）が 維持されるのに対して, 本研究が対象としている実験領域 の LSD は本質的に衝撃波誘起でなく，レーザー加熱がそ の加熱層の途中に衝撃波を誘起・維持していると考えられ る。衝撃波誘起でないため, 衝撃波とプラズマ層が一度離 れると上記のような LSD 構造が維持されない. すなわち, 種電子の生成等によって衝撃波より前方に先行加熱領域が 形成されることが, LSDの維持に必要不可欠であると考え られる。 


\section{5. ま と め}

・TEA $\mathrm{CO}_{2}$ パルスレーザー誘起爆轟波内部を光学計測 し, 電子温度, 数密度分布を得た。 $n_{\mathrm{e}}$ のピーク值は $2 \times 10^{24} \mathrm{~m}^{-3}$ 程度, $T_{\mathrm{e}}$ は約 $32,000 \mathrm{~K}$ で, 時間の経過 とともに減少した.

・計測結果を用いて吸収係数分布を算出した結果，衝撃波 背後の薄いレーザー吸収層でレーザーエネルギーが完全 に吸収されることが示された。また $\Delta x$ は $l$ よりも厚く, レーザーに支持されていないプラズマがレーザー吸収層 背後に広く残存していることを示し, Raizerの LSD モ デルが適用できないことがわかった。

・LSD が維持されている時間帯では, 衝撃波面にすでにプ ラズマが存在し, 衝撃波より前方にもプラズマが存在す ることが示唆された。すなわち, LSDの維持には衝撃波 前方に種電子の生成等によって先行加熱領域が形成され ることが必要不可欠であると考えられる。

本研究は, 独立行政法人日本学術振興会科学研究費補助 金基盤研究 (A) No. 19206087 の補助を受けた.

\section{参 考 文 献}

1) Kantrowitz, A.: Propulsion to Orbit by Ground Based Lasers, Aeronaut. Astronaut., 10 (1972), pp. 74-76.

2) Myrabo, L. M., Messit, D. G. and Mead, F. B. Jr.: Ground and Flight Tests of a Laser Propelled Vehicle, AIAA Paper
98-1001, 1998

3) Katsurayama, H., Komurasaki, K. and Arakawa, Y.: A Preliminary Study of Laser Powered Launcher Performance, Acta Astronautica, 65 (2009), pp. 1032-1041.

4) Mori, K., Komurasaki, K. and Arakawa, Y.: Nozzle Scale Optimum for the Impulse Generation in a Laser Pulsejet, J. Spacecraft Rockets, 41 (2004), pp. 887-889.

5) Katsurayama, H., Komurasaki, K., Hirooka, Y., Mori, K. and Arakawa, Y.: Numerical Analysis of Exhaust and Refill Process of a Laser Pulsejet, J. Propul. Power, 24 (2008), pp. 999-1006.

6) Raizer, Y. P.: Laser-Induced Discharge Phenomena, Consultant Bureau, California, 1985, pp. 199-204.

7) Mori, K., Komurasaki, K. and Arakawa, Y.: Influence of the Focusing $f$ Number on the Heating Regime Transition in Laser Absorption Waves, J. Appl. Phys., 15 (2002), pp. $5663-5667$.

8) Mori, K., Komurasaki, K. and Arakawa, Y.: Energy Transfer from a Laser Pulse to a Blast Wave in Reduced-Pressure Air Atmospheres, J. Appl. Phys., 95 (2004), pp. 5979-5983.

9) Mori, K., Komurasaki, K. and Arakawa, Y.: Threshold Laser Power Density for Regime Transition of a Laser Absorption Wave in a Reduced-Density Air Atmosphere, Appl. Phys. Lett., 88 (2006), 121502.

10) Ushio, M., Komurasaki, K., Kawamura, K. and Arakawa, Y.: Effect of Laser Supported Detonation Wave Confinement on Termination Conditions, Shock Waves, 18 (2008), pp. 35-39.

11）流れの可視化学会: 流れの可視化ハンドブック, 朝倉書店, 東京, 1986, pp. 291-367.

12) Kemp, N. H. and Lewis, P. F.: Laser-Heated Thruster, NASA CR-161665, 1980

13) 加藤 進, 高橋栄一, 佐々木明, 岸本泰明: 放電・雷に扮ける原 子・分子過程のモデル化, J. Plasma Fusion Res., 84 (2008), pp. $477-485$. 